\title{
PENGEMBANGAN MODEL EVALUASI PROGRAM PEMBELAJARAN SEJARAH DI SMA
}

\author{
Aman \\ Fakultas Ilmu Sosial Universitas Negeri Yogyakarta \\ kangaman74@yahoo.com
}

\begin{abstract}
Abstrak
Penelitian ini menemukan model evaluasi pembelajaran sejarah yang dapat memberikan informasi yang tepat dan akurat bagi pimpinan sekolah dan guru serta bermanfaat secara optimal bagi pelaksanaan program pembelajaran sejarah di SMA. Model pengembangan yang digunakan pada penelitian dan pengembangan ini memakai model Borg and Gall dengan memodifikasi 10 tahapan penelitian menjadi 4 tahap penelitian. Uji coba dalam penelitian dan pengembangan dilakukan tiga tahap yakni uji coba pendahuluan melibatkan 20 orang pakar dan praktisi pendidikan, uji coba utama diterapkan pada 241 subjek coba di SMA Negeri I Prambanan Klaten, dan uji coba operasional diterapkan pada 377 subjek coba di SMA Negeri I Yogyakarta, SMA Negeri 5 Yogyakarta, SMA Islam I Gamping Sleman, dan SMA Muhammadiyah Wates dengan melibatkan kepala sekolah, guru, dan siswa. Penelitian menyimpulkan bahwa model evaluasi pembelajaran sejarah (EPS), memiliki dua komponen evaluasi program, yakni komponen kualitas pembelajaran dan hasil pembelajaran sejarah. Kualitas pembelajaran sejarah terdiri dari tujuh komponen, yakni: kinerja guru sejarah, materi pelajaran, metode pembelajaran, sarana pembelajaran, suasana pembelajaran, sikap siswa, dan motivasi belajar sejarah, sedangkan hasil pembelajaran sejarah terdiri dari tiga komponen yakni: kecakapan akademik, kesadaran sejarah, dan sikap nasionalisme. Model EPS memiliki beberapa karakteristik yang membedakan dengan evaluasi model lain, yakni: (a) model digunakan untuk mengevaluasi program pelaksanaan pembelajaran sejarah di SMA, (b) tidak tergantung pada pendekatan pembelajaran tertentu, (c) komprehensif, (d) dapat digunakan sebagai evaluasi diagnostik, (e) bersifat terbuka untuk dikembangkan lebih lanjut.
\end{abstract}

Kata Kunci: pengembangan model, evaluasi program, pembelajaran sejarah, SMA 
Jurnal Penelitian dan Evaluasi Pendidikan

\title{
DEVELOPING MODEL OF HISTORY LEARNING EVALUATION PROGRAM IN SMA
}

\author{
Aman \\ Fakultas Ilmu Sosial Universitas Negeri Yogyakarta \\ kangaman74@yahoo.com
}

\begin{abstract}
Abstrak
This study discovers a model for the history learning evaluation (HLE) that can give accurate information to the principal and teacher and is optimally useful for the implementation of history learning programs in SHSs. This research used model developed by Borg and Gall with modification from 10 steps to 4 steps. The tryouts in this research and development study were conducted in three stages, i.e. the preliminary tryout involving 20 education experts and practitioners, the main tryout involving 241 subjects in SMA Negeri I Prambanan Klaten, and the operational tryout involving 377 subjects in SMA Negeri I Yogyakarta, SMA Negeri 5 Yogyakarta, SMA Islam I Gamping Sleman, and SMA Muhammadiyah Wates, and involving the principals, teachers, and students. The study concluded that the HLE model has two components of program evaluation: the history learning quality and learning result. The history learning quality consists of seven components, i.e. history teachers' performance, history learning materials, teaching methods, history learning sources, learning atmosphere, student attitudes, and history learning motivation. The history learning results consist of three components: academic capability, history awareness, and nationalism attitude. The HLE model has some characteristics which are different from other evaluation models in that: (a) it is used to evaluate learning history program implementation in senior high schools, (b) it does not depend on a certain learning method, (c) it is comprehensive, (d) it can be used as a diagnostic evaluation, and (e) it is open for further development.
\end{abstract}

Keywords: the development model, program evaluation, learning history, high school 


\section{Pendahuluan}

Dalam rangka meningkatkan kualitas pendidikan nasional, pemerintah telah melakukan berbagai upaya seperti pengembangan dan penyempurnaan kurikulum, pengembangan materi pembelajaran, perbaikan sistem evaluasi, pengadaan buku dan alat-alat pelajaran, perbaikan sarana prasarana pendidikan, peningkatan kompetensi guru, serta peningkatan mutu pimpinan sekolah. Namun demikian, upaya tersebut belum menunjukkan hasil sebagaimana yang diharapkan. Kualitas pendidikan dipengaruhi beberapa faktor, seperti: guru, siswa, pengelola sekolah, lingkungan (orangtua, masyarakat, sekolah), kualitas pembelajaran, dan kurikulum.

Selama ini, pembelajaran sejarah di sekolah kurang begitu diminati oleh peserta didik. Pelajaran sejarah dianggap sebagai pelajaran yang membosankan karena seolah-olah cenderung "hafalan". Bahkan kebanyakan siswa menganggap bahwa pelajaran sejarah tidak membawa manfaat karena kajiannya adalah masa lampau. Tidak memiliki sumbangan yang berarti bagi dinamika dan pembangunan bangsa. Oleh karena itu, pelajaran sejarah hanya dianggap sebagai pelajaran pelengkap, apalagi mata pelajaran ini tidak di ujikan secara nasional. Ditambah lagi dengan kebijakan pemerintah yang semakin menyempitkan gerak langkah pembelajaran sejarah, yakni dengan semakin kecilnya porsi jam pelajaran sejarah di sekolah. Tidak mengherankan jika prestasi belajar sejarah siswa juga cenderung kurang memuaskan.

Setiap kegiatan pendidikan, seharusnya diikuti dengan kegiatan evaluasi. Evaluasi dilakukan bertujuan untuk menilai apakah suatu program terlaksana sesuai dengan perencanaan dan mencapai hasil sesuai yang diharapan atau belum. Berdasarkan hasil evaluasi akan dapat diketahui halhal yang telah dicapai, apakah suatu program dapat memenuhi kriteria yang telah ditentukan. Setelah itu kemudian diambil keputusan apakah program tersebut diteruskan, direvisi, dihentikan, atau dirumuskan kembali sehingga dapat ditemukan tujuan, sasaran dan alternatif baru yang sama sekali berbeda dengan format sebelumnya. Agar dapat menyusun program yang lebih baik, maka hasil evaluasi program sebelumnya dapat dijadikan sebagai 
acuan pokok. Menurut Scriven dalam Fernandes (1984) bahwa dua fungsi dasar evaluasi adalah untuk memperbaiki dan mengembangkan sebuah program.

Secara umum, evaluasi merupakan proses mengumpulkan informasi untuk mengetahui pencapaian belajar peserta didik (Mardapi, 2005: 75). Evaluasi proses dan hasil belajar bertujuan untuk menentukan tingkat ketercapaian tujuan pendidikan yang telah ditetapkan. Suharsimi Arikunto (2001: 9-11) mengemukakan bahwa penilaian dilakukan bertujuan: 1) merangsang aktivitas siswa; 2) menemukan penyebab kemajuan atau kegagalan pembelajaran; 3) memberi bimbingan yang sesuai; 4) memberi laporan tentang kemajuan siswa kepada orangtua dan lembaga pendidikan terkait; dan 5) sebagai feed back. Sebuah program bukan hanya kegiatan tunggal, melainkan kegiatan yang berkesinambungan karena melaksanakan suatu kebijakan (Arikunto dan Cepi, 2004: 3). Pola semacam ini memungkinkan terciptanya peningkatan proses pembelajaran yang kondusif (Carolin Rekar Murno, 2005).

Suatu hal yang lebih penting adalah bahwa program pembelajaran sejarah harus dievaluasi secara profesional sehingga di samping memberikan informasi yang akurat bagi pimpinan sekolah, tentunya yang paling penting adalah bagaimana program pembelajaran sejarah baik dari segi proses maupun hasil dapat menunjukkan kualitas yang baik melalui evaluasi secara berkelanjutan. Oleh karena itu, perlu dievaluasi perangkatperangkat pendukung pembelajaran sejarah, seperti halnya yang menyangkut kinerja guru, sarana pendukung, motivasi dan sikap siswa, iklim kelas, materi pelajaran, dan lain sebagainya yang berhubungan dengan keberhasilan program pembelajaran sejarah di SMA.

Dalam proses pendidikan, sejarah memiliki peranan penting bagi character and nation building. Seseorang yang mempelajari sejarah, harus memahami hubungkait antara sejarah sebagai ilmu, dan sejarah sebagai pendidikan. Hubungan antara konsep dasar sejarah dan pelajaran sejarah di sekolah, dijelaskan dalam Permendiknas No 22 Tahun 2006 bahwa sejarah merupakan cabang ilmu pengetahuan yang menelaah tentang asal-usul dan perkembangan serta peranan masyarakat di masa lampau berdasarkan metode dan metodologi tertentu. Terkait dengan pendidikan di sekolah 
dasar hingga sekolah menengah, pengetahuan masa lampau tersebut mengandung nilai-nilai kearifan yang dapat digunakan untuk melatih kecerdasan, membentuk sikap, watak dan kepribadian peserta didik (Depdiknas, 2006: 523).

Edward Hallet Carr (Maarif, 2006: 41) menjelaskan bahwa " History is a continuous process of interaction between the historian and the his facs, and unending dialogue between the present and the past". (Sejarah adalah sebuah proses interaksi tanpa henti antara sejarawan dan fakta-faktanya, sebuah dialog yang tak berujung antara masa sekarang dan masa lampau). Sejarah mencerminkan nilai kemasakinian dan nilai kemasakinian dari sejarah itu adalah semangat yang sebenarnya berasal dari kepentingan mempelajari sejarah. Hanya melalui memproyeksikan peristiwa masa lampau ke masa kini maka kita baru akan dapat berbicara tentang makna edukatif sejarah. Dalam kemasakinianlah masa lampau itu benar-benar masa lampau yang penuh makna, the meaningful of past dan bukan masa lampau yang mati dan final, the final and dead of past.

Pembelajaran sejarah di sekolah, dilaksanakan dalam rangka untuk mencapai sasaran hasil pembelajaran yaitu academic skill (kecakapan akademik), historical consiousness (kesadaran sejarah), dan nationalism (nasionalisme), yang tentu harus dilandasi oleh kualitas proses pembelajaran yang memadai. Secara umum pembelajaran sejarah bertujuan untuk membentuk warga negara yang baik, dan menyadarkan peserta didik untuk mengenal diri dan lingkungannya, serta memberikan perspektif historikalitas. Sejarah mengajarkan apa yang tidak dapat di lihat, untuk memperkenalkan kita pada penglihatan yang kabur sejak kita lahir. (Wineburg, 2006: 7).

Pertama, pembelajaran sejarah dalam rangka pengembangan academic skill ada tiga yaitu, mengajarkan konsep, mengajarkan keterampilan intelektual, dan memberikan informasi kepada peserta didik. Adapun langkah-langkah memahami pelajaran sejarah secara bermakna ada lima langkah yakni: pre-structural, uni-structural, multi-structural, relational, dan ektended (Ian Phillips, 2008: 17). Kecakapan ini diawali dengan tahap yang sifatnya sederhana sampai pada level yang sifatnya kompleks berupa kemampuan berpikir orisinil. Dimensi academic skill menurut Parinas, 
mencakup pengetahuan faktual, konseptual, prosedural, dan meta-kognitif (Pujiyati Suyata, 2011: 1).

Kedua, kesadaran sejarah. Pembelajaran sejarah memiliki fungsi yang sangat fundamental yakni untuk menciptakan kesadaran nasional yang pada gilirannya memperkokoh solidaritas nasional. Sehubungan dengan itu pelajaran sejarah nasional amat strategis fungsinya bagi pembentukan kesadaran sejarah. Tanpa sejarah orang tidak akan mampu membangun ide-ide tentang konsekuensi dari apa yang dia lakukan dalam realitas kehidupannya pada masa kini dan masa yang akan datang, dalam sebuah kesadaran historis. Dalam kaitan ini, Collingwood (Maarif, 2006: 38) sejarawan Inggris menyatakan sebagai berikut:

"...knowing your self means knowing that you can do; and since nobody knows what he can do untul he tries, the only clue to what man can do is what man has done. The value of history, then, is that it theachs us what man has done and then what man is..."

Dalam hal ini, mengenal diri sendiri itu berarti mengenal apa yang dapat seseorang lakukan, dan karena tidak seorang pun mengetahui apa yang bisa dia lakukan sampai dia mencobanya, maka satu-satunya kunci untuk mengetahui apa yang dia bisa perbuat seseorang adalah apa yang telah diperbuat. Nilai dari sejarah adalah bahwa sejarah telah mengajarkan tentang apa yang telah manusia kerjakan, dan apa sebenarnya manusia itu. Kemampuan seseorang untuk melaksanakan tugas tertentu akan mewujudkan perilaku yang diharapkan bisa menyelesaikan tugas kehidupan dengan baik (Michael Armstrong dan Helen Murlis, 2003: 50).

Ketiga, menanamkan sikap nasionalisme. Permendiknas No 22 Tahun 2006 merumuskan bahwa mata pelajaran sejarah memiliki arti strategis dalam pembentukan watak dan peradaban bangsa yang bermartabat serta dalam pembentukan manusia Indonesia yang memiliki rasa kebangsaan dan cinta tanah air. Materi sejarah mengandung nilai-nilai kepahlawanan, keteladanan, kepeloporan, patriotisme, nasionalisme, dan semangat pantang menyerah yang mendasari proses pembentukan watak dan kepribadian peserta didik; memuat khasanah mengenai peradaban bangsa-bangsa, termasuk peradaban bangsa Indonesia. Pembelajaran 
sejarah sebagai sarana pendidikan bangsa, terutama dalam aplikasi sejarah normatif, memiliki tujuan, substansi, dan sasaran pada segi-segi yang bersifat normatif (Djoko Suryo (2005: 3). Pendekatan pembelajaran sejarah yang menekankan pada student centered, reflective learning, active learning, enjoyble dan joyful learning, cooperative learning, quantum learning, learning revolution, dan contectual learning, tentu akan menumbuhkan semangat nasionalisme dan integrasi nasional, terutama jika menggunakan pendekatan yang cocok yakni pendekatan multiperspektif dan multikultural (Wiriaatmadja, 2004: 62).

Hans Kohn, seorang sejarawan yang cukup terkenal dan paling banyak karya tulisnya mengenai nasionalisme, memberikan terminologi yang sampai saat ini masih tetap digunakan secara relevan dalam pembelajaran di sekolah, yakni: "nationalism is a state of mind in which the supreme loyalty of individual is felt to be due the nation state". Bahwa nasionalisme merupakan suatu faham yang memandang bahwa kesetiaan tertinggi individu harus diserahkan kepada negara kebangsaan (A Daliman, 2006: 53). Semangat nasionalisme dalam negara kebangsaan dijiwai oleh lima prinsip nasionalisme, yakni: 1) kesatuan (unity), 2) kebebasan (liberty, freedom, independence), 3) kesamaan (equality), 4) kepribadian (personality) dan identitas (identity), 5) prestasi (achievement) (Sartono Kartodirdjo, 1999: 7-8).

Keberhasilan program pembelajaran selalu dilihat dari hasil belajar yang dicapai. Sebenarnya evaluasi pembelajaran memerlukan data tentang pelaksanaan pembelajaran dan tingkat ketercapaian tujuannya. Evaluasi pembelajaran seringkali hanya didasarkan pada penilaian aspek hasil belajar, sementara kualitas proses pembelajaran yang berlangsung jarang tersentuh kegiatan penilaian. Fokus penilaian adalah individu, sedang fokus evaluasi adalah kelompok (Mardapi, 2011: 2). Komponen evaluasi program yang sifatnya kelompok terhadap kualitas pembelajaran mencakup kinerja guru, materi pembelajaran, metode, sarana, suasana kelas, sikap siswa, dan motivasi dalam belajar sejarah. Berdasarkan permasalahan itulah maka diperlukan penelitian pengembangan model evaluasi program pembelajaran sejarah di SMA yang fokusnya adalah sasaran evaluasi proses dan hasil belajar sejarah di SMA. Berdasar pada permasalahan penelitian di atas, tujuan penelitian ini mengembangkan sebuah model evaluasi pembelajaran 
sejarah yang dapat memberikan informasi dengan tepat bagi pimpinan sekolah dan guru baik dari segi isi, cakupan, format maupun waktu penyampaian serta bermanfaat secara optimal bagi pelaksanaan pembelajaran sejarah di SMA.

\section{Metode Penelitian}

Penelitian ini menggunakan metode Penelitian Pengembangan (Research and Development). Menurut Borg and Gall (1989:782), yang dimaksud dengan model penelitian dan pengembangan adalah "a process used develop and validate educational product". Kadang-kadang penelitian ini juga disebut 'research based development', yang muncul sebagai strategi dan bertujuan untuk meningkatkan kualitas pendidikan. Selain untuk mengembangkan dan memvalidasi hasil-hasil pendidikan, Research and Development juga bertujuan untuk menemukan pengetahuan-pengetahuan baru melalui 'basic research', atau untuk menjawab pertanyaan-pertanyaan khusus tentang masalah-masalah yang bersifat praktis melalui 'applied research', yang digunakan untuk meningkatkan praktik-praktik pendidikan. Gay (1981: 10) mengatakan bahwa tujuan utama dari Research and Development tidak dimaksudkan untuk menguji hipotesis, melainkan untuk menghasilkan produk-produk efektif untuk digunakan di sekolah. Adapun pendekatan penelitian yang digunakan adalah mixing method dengan memadu pendekatan kuantitatif dan kualitatif (Brannen, 1993: 3-8).

Secara konseptual dan prosedural, model pengembangan yang digunakan sebagai kajian pada penelitian dan pengembangan ini mengacu pada model Borg and Gall dengan memodifikasi 10 tahapan penelitian menjadi 4 tahap penelitian, yang pada intinya sama melalui langkah-langkah Borg and Gall tersebut. Demikian juga dengan penentuan jumlah subjek ujicoba mengacu pada model Borg and Gall, yakni jumlah subjek ujicoba dari pertama, kedua dan seterusnya semakin meningkat. Borg and Gall memberikan rujukan kepada peneliti bahwa untuk melakukan penelitian pengembangan, mereka menetapkan sepuluh langkah utama sebagai berikut. 


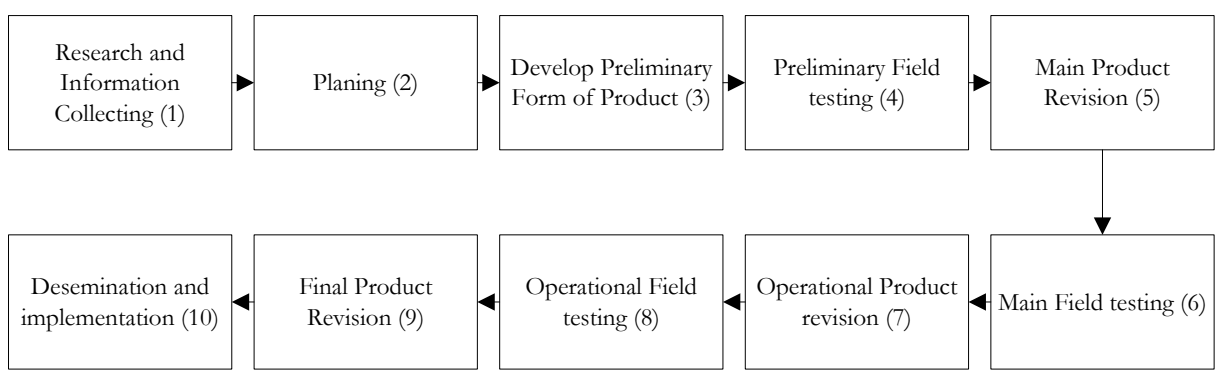

Gambar 1. Model R\&D Borg and Gall

Langkah (1) penelitian dan pengumpulan informasi, dalam model ini disebut sebagai tahap penelitian pendahuluan; langkah (2) perencanaan dan (3) pengembangan produk awal, disebut sebagai tahap penencanaan karena pada dasarnya kedua langkah tersebut merupakan tahap perencanaan baik perencanaan instrument pengumpul data, perangkat evaluasi, maupun desain uji coba model evaluasi; langkah (4) uji coba pendahuluan, (5) revisi produk utama, (6) uji coba utama, (7) revisi produk operasional, dalam model ini disebut sebagai tahap uji coba, evaluasi, dan revisi; dan langkah (8) uji coba operasional lapangan, (9) revisi produk akhir, (10) deseminasi dan implementasi, dalam model penelitian ini disebut sebagai tahap implementasi.

Adapun langkah-langkah dalam metode penelitian pengembangan ini setelah disesuaikan dengan evaluasi model CIPP yang difokuskan pada input, proses dan output adalah sebagai berikut.

\section{Tahap Pendahuluan}

Tahap ini merupakan tahap penelitian dan pengumpulan informasi terkait dengan sistem evaluasi pembelajaran sejarah di SMA. Belum ditemukannya model evaluasi pembelajaran sejarah di SMA yang dapat memberikan informasi lengkap dan akurat bagi pimpinan sekolah, merupakan masalah pokok yang akan dicarikan pemecahannya. Oleh karena itu, kegiatan yang dilakukan pada tahap ini adalah melakukan penelitian pendahuluan ke beberapa SMA tentang kegiatan evaluasi 
pembelajaran sejarah, mengkaji karya-karya tentang teori-teori yang dapat menjadi pendukung seperti teori yang berkaitan sejarah dan pembelajaran sejarah, teori model-model evaluasi serta melakukan identifikasi masalah mengkaji hasil-hasil penelitian sebelumnya yang relevan.

\section{Tahap Perencanaan}

Tahap ini merupakan tahap perencanaan model evaluasi pembelajaran sejarah di SMA dan perencanaan instrumen pengumpul data serta perangkat model evaluasinya. Di samping itu, disusun pula desain uji coba model evaluasi sebagai pengembangan bentuk produk awal.

Tahap Uji Coba, Evaluasi dan Revisi

Tahap ini merupakan tahap uji coba lapangan tingkat pendahuluan, dimana model evaluasi beserta instrumen dan perangkat modelnya diterapkan dengan tujuan untuk mengetahui sejauh mana model evaluasi tersebut dapat diterapkan untuk mengevaluasi pembelajaran sejarah di SMA. Uji coba pertama oleh Borg and Gall disebut dengan uji coba pendahuluan kemudian dievaluasi dan revisi untuk dilanjutkan pada uji coba kedua sebagai uji coba utama. Uji coba utama dievaluasi dan direvisi sehingga model sudah baik dan siap untuk diterapkan pada uji coba secara operasional pada tahap implementasi.

\section{Tahap Implementasi}

Setelah model dianggap sudah baik, maka model evaluasi beserta perangkat yang telah diujicobakan kemudian diterapkan pada sekolah lain agar dapat evaluasi sejauh mana hasil penerapannya. Jika hasil penerapan tersebut masih ada hal-hal yang perlu dibenahi, maka perlu dilakukan perbaikan sebagaimana mestinya. Hasil nya merupakan sebuah model evaluasi pembelajaran sejarah (EPS) beserta instrumen dan perangkatnya. 


\section{Hasil Penelitian dan Pembahasan}

Model evaluasi yang dikembangkan dalam penelitian ini adalah model evaluasi yang digunakan untuk mengevaluasi pelaksanaan pembelajaran sejarah di Sekolah Menengah Atas (SMA). Kegiatan Research and Development (R\&D) melalui pra-survei, kajian teoretik termasuk kajian penelitian yang relevan, empirik, dan praktik di lapangan pada akhirnya menemukan konsep kualitas dan hasil pembelajaran sejarah. Konsep kualitas dan hasil pembelajaran yang dihasilkan melalui proses panjang seperti diskusi panel, diskusi terfokus (FGD), seminar instrumen, dan uji coba produk di lapangan. Sebelum model ini diujicobakan, semua instrumen dan perangkatnya telah divalidasi oleh para pakar dan praktisi pendidikan sejarah. Kajian teoretik, empirik, dan praktik di lapangan serta diskusi intensif dengan promotor disertasi dan berbagai pihak melalui uji coba lapangan menunjukkan bahwa konsep kualitas dan hasil pembelajaran sejarah yang baru menawarkan komponen dan indikator yang lebih komprehensif, yakni konsep yang lebih padat menyeluruh, dan terintegrasi pada 7 (tujuh) komponen kualitas, dan 3 (tiga) komponen hasil pembelajaran sejarah sebagai produk akhir yang merupakan hasil penelitian pengembangan ini. Selanjutnya produk pengembangan dideskripsikan pada pedoman Evaluasi Pembelajaran Sejarah di SMA pada lampiran disertasi ini. Berikut ini dijelaskan secara sistematis data uji coba lapangan tahap pertama, kedua, dan ketiga sebagai hasil penelitian pengembangan dalam studi ini adalah sebagai berikut.

Pelaksanaan FGD (Focus Group Discusion) diselenggarakan pada tanggal 14 April 2010 dengan melibatkan berbagai pihak yakni pihak internal sekolah yakni kepala sekolah atau pimpinan sekolah dan guru sejarah serta pihak eksternal yakni melibatkan pakar dan praktisi pendidikan. Adapun jumlah peserta FGD 23 orang dengan rincian dosen pendidikan sejarah (9 orang) termasuk promotor disertasi, ahli evaluasi pendidikan (6 orang), guru sejarah (5 orang), kepala sekolah belatarbelakang sejarah (2 orang), dan unsur Masyarakat Sejarawan Indonesia (1 orang). Melalui FGD yang dilaksanakan secara intensif dan efektif, dengan melibatkan berbagai pakar baik internal maupun eksternal, 
pada akhirnya menemukan dan menetapkan konsep kualitas dan hasil pembelajaran sejarah. Di samping itu, draf awal instrumen juga didiskusikan dan menampung banyak masukan-masukan atau rekomendasi untuk menyederhanakan jumlah instrumen yang terlalu banyak.

Kemudian setelah dilakukan perbaikan terhadap komponen dan indikator evaluasi program pembelajaran sejarah, serta perbaikan instrumen, maka dilakukan seminar instrumen terbatas tanggal 16 April 2010 dengan melibatkan 14 orang ahli yang terdiri atas dosen pendidikan sejarah (5 orang), Mahasiswa S-3 PEP (5 orang), dan guru sejarah (4 orang). Sebelum model diujicobakan pada subjek coba, seluruh instrumen beserta perangkatnya telah divalidasi oleh para pakar dan praktisi pendidikan sejarah melalui uji coba pendahuluan terhadap 20 ahli yang terdiri atas dosen pendidikan sejarah (4 orang), pengawas IPS belatarbelakang sejarah (4 orang), kepala sekolah (4 orang) guru sejarah (4 orang), dan ahli evaluasi (4 orang).

Penilai model evaluasi yang terlibat tahap kedua berjumlah 24 orang, yakni 7 dosen pendidikan sejarah, 5 pakar evaluasi pendidikan, 5 kepala sekolah atau pimpinan sekolah, 7 guru sejarah. Uji coba dilaksanakan pertengahan bulan Mei 2010. Sedangkan validator instrumen kualitas dan hasil pembelajaran sejarah tahap II berjumlah 84 orang, yakni terdiri dari 24 pakar yakni: 7 dosen pendidikan sejarah, 5 pakar evaluasi pendidikan, 5 kepala sekolah atau pimpinan sekolah, 7 guru sejarah, dan 60 siswa kelas XI dari SMA N I Prambanan Klaten. Siswa yang diminta untuk menjadi validator diambil secara random dari kelas XI yang menjadi tempat uji coba utama. Selain guru dan kepala sekolah SMA N I Prambanan tersebut, penilai juga melibatkan beberapa guru dan kepala sekolah SMA lain.

Penilai model evaluasi yang terlibat dalam penilaian tahap tiga berjumlah 38 orang, yakni dosen ahli evaluasi dan pendidikan sejarah (17 orang), kepala sekolah (7), dan guru sejarah (14 orang). Sedangkan validator terhadap instrumen kualitas dan hasil pembelajaran tahap ketiga berjumlah 104 orang, yakni pimpinan sekolah (7 orang), pakar evaluasi pendidikan (5 orang), dan dosen pendidikan sejarah (12 orang), guru sejarah (14 orang) termasuk guru sejarah SMA N 1 Yogyakarta (2 orang), siswa (29 orang); guru sejarah SMA N 5 Yogyakarta (2 orang), siswa (23 orang); guru SMA 
Islam I Gamping (2 orang) dan siswa ( 6 orang), guru SMA Muhammadiyah Wates (1 orang) dan siswa (8 orang). Selain guru dan kepala sekolah SMA tersebut di atas, penilai juga melibatkan beberapa guru dan kepala sekolah SMA lain. Penilaian tahap ketiga ini dilaksanakan pada akhir bulan Mei sampai Juni 2010. Adapun rekapitulasi hasil validasi terhadap model evaluasi pembelajaran sejarah yang mencakup sasaran evaluasi proses dan hasil belajar tersaji dalam tabel 1 di bawah ini.

Tabel 1. Hasil Validasi Instrumen Kualitas Pembelajaran Sejarah

\begin{tabular}{|c|c|c|c|c|c|c|c|c|c|c|c|c|c|c|c|c|}
\hline \multirow[t]{2}{*}{ Tahap } & \multirow{2}{*}{$\begin{array}{l}\text { Jml } \\
\text { Resp }\end{array}$} & \multicolumn{14}{|c|}{ Rerata Skor Butir } & \multirow{2}{*}{$\begin{array}{r}\text { Rerata } \\
\text { Total }\end{array}$} \\
\hline & & 1 & 2 & 3 & 4 & 5 & 6 & 7 & 8 & 9 & 10 & 11 & 12 & 13 & 14 & \\
\hline 1 & 20 & 3,70 & 3,95 & 4,00 & 3,80 & 3,80 & 3,95 & 3,85 & 3,95 & 3,70 & 3,90 & 3,95 & 3,80 & 3,90 & 3,85 & 3,86 \\
\hline 2 & 84 & 4,05 & 3,86 & 3,99 & 3,77 & 3,82 & 3,92 & 3,93 & 4,10 & $3, .99$ & 4,05 & 4,04 & 4,15 & 4,04 & 3,95 & 3,98 \\
\hline 3 & 104 & 4,07 & 3,94 & 3,97 & 3,85 & 3,87 & 3,93 & 3,96 & 4,07 & 4,07 & 4,11 & 4,15 & 4,20 & 4,11 & 4,07 & 4,02 \\
\hline
\end{tabular}

Rerata skor total hasil validasi instrumen kualitas pembelajaran sejarah ketiga tahap tersebut berada pada interval $>3,4-4,2$ yang berarti kategori baik sehingga instrumen dapat digunakan tanpa perbaikan. Karena instrumen belum memiliki klasifikasi sangat baik, maka instrumen tersebut tetap dilakukan perbaikan. Dengan demikian, sebelum instrumen diujicoba pada tahap ketiga, maka terlebih dulu dilakukan perbaikan-perbaikan mengacu pada rekomendasi yang diberikan oleh validator. Terdapat beberapa rekomendasi yang diberikan oleh para validator dan merupakan dasar dilakukannya perbaikan sebelum dilakukan ujicoba tahap ketiga.

Tabel 2. Rekapitulasi Hasil Validasi Instrumen Hasil Pembelajaran Sejarah

\begin{tabular}{|c|c|c|c|c|c|c|c|c|c|c|c|}
\hline \multirow[t]{2}{*}{ Tahap } & \multirow{2}{*}{$\begin{array}{l}\text { Jml } \\
\text { Resp }\end{array}$} & \multicolumn{9}{|c|}{ Rerata Skor Butir } & \multirow{2}{*}{$\begin{array}{c}\text { Rerata } \\
\text { Total }\end{array}$} \\
\hline & & 1 & 2 & 3 & 4 & 5 & 6 & 7 & 8 & 9 & \\
\hline 1 & 20 & 3,95 & 3,95 & 4,05 & 3,70 & 3,85 & 3,85 & 3,85 & 3,90 & 3,85 & 3,88 \\
\hline 2 & 84 & 4,01 & 4,11 & 4,07 & 4,11 & 3,96 & 4,05 & 4,26 & 4,05 & 4,11 & 4,07 \\
\hline 3 & 104 & 4,12 & 4,12 & 4,10 & 4,13 & 3,98 & 4,13 & 4,35 & 4,11 & 4,15 & 4,13 \\
\hline
\end{tabular}


Rerata skor total hasil validasi instrumen hasil pembelajaran sejarah ketiga tahap tersebut berada pada interval $>3,4-4,2$ masuk dalam klasifikasi baik sehingga instrumen layak digunakan tanpa perbaikan. Rerata skor total hasil penilaian tahap ketiga mengalami peningkatan dari rerata 4.07 menjadi 4.13. Meskipun terjadi peningkatan, hasil penilaian tahap akhir tersebut masih dalam klasifikasi baik, yang artinya instrumen baik untuk digunakan di jenjang sekolah menengah atas di segala klasifikasi sekolah. Terjadinya peningkatan rerata skor tersebut menunjukkan bahwa ada hubungan yang positif dengan revisi yang dilakukan sebelumnya.

Tabel 3. Rekapitulasi Hasil Penilaian Model Evaluasi

\begin{tabular}{|c|c|c|c|c|c|c|c|c|c|}
\hline Tahap & Jumlah & \multicolumn{7}{|c|}{ Rerata Skor Butir } & Rerata \\
& Resp & 1 & 2 & 3 & 4 & 5 & 6 & 7 & Total \\
\hline 1 & 20 & 4,00 & 3,90 & 3,90 & 4,05 & 3,95 & 4,00 & 3,95 & 3,96 \\
\hline 2 & 24 & 4,21 & 4,25 & 4,13 & 4,21 & 4,13 & 4,13 & 4,13 & 4,17 \\
\hline 3 & 38 & 4,11 & 4,16 & 4,16 & 4,21 & 4,03 & 4,00 & 3,95 & 4,09 \\
\hline
\end{tabular}

Jika rerata total skor tersebut dibandingkan dengan tabel standar penilaian pada panduan evaluasi, maka dapat disimpulkan bahwa model evaluasi termasuk klasifikasi baik sehingga layak digunakan untuk mengevaluasi program pembelajaran sejarah di SMA. Penilaian ketiga mengalami sedikit penurunan dari 4,17 menjadi 4,09. Meskipun terjadi penurunan dari 4,17 menjadi 4,09, tetapi klasifikasinya tidak berubah yakni klasifikasi baik, sehingga model ini baik untuk digunakan di sekolah menengah atas. Berdasarkan hasil analisis tersebut menunjukkan bahwa evaluasi model EPS beserta perangkatnya memiliki sifat objektivitas, praktikabilitas dan efisiensi atau ekonomis yang cukup baik.

Jika dibandingkan dengan penilaian kedua, penilaian tahap ketiga tidak mengalami kenaikan, yaitu dari 4,23 menjadi 4,23, yakni klasifikasi sangat baik. Tetapi jika dibandingkan dengan tahap pertama ada perbedaan hasil yakni dari klasifikasi baik menjadi sangat baik. Mengacu pada hasil ketiga tahap penilaian tersebut, maka dapat dikategorikan bahwa panduan 
evaluasi yang dikembangkan dalam penelitian ini sudah dapat digunakan oleh kepala sekolah untuk melaksanakan evaluasi pembelajaran sejarah di SMA dengan menggunakan model EPS.

Tabel 4. Rekapitulasi Hasil Penilaian Panduan Evaluasi

\begin{tabular}{|c|c|c|c|c|c|c|c|c|c|}
\hline \multirow{2}{*}{ Tahap } & Jumlah & \multicolumn{7}{|c|}{ Rerata Skor Butir } & \multirow{2}{*}{$\begin{array}{c}\text { Rerata } \\
\text { Total }\end{array}$} \\
\cline { 3 - 9 } & Resp & 1 & 2 & 3 & 4 & 5 & 6 & 7 & \\
\hline 1 & 20 & 3,90 & 3,90 & 4,00 & 3,90 & 4,05 & 3,95 & 4,05 & 3,96 \\
\hline 2 & 24 & 4,29 & 4,29 & 4,21 & 4,21 & 4,25 & 4,25 & 4,13 & 4,23 \\
\hline 3 & 38 & 4,37 & 4,26 & 4,08 & 4,08 & 4,29 & 4,21 & 4,34 & 4,23 \\
\hline
\end{tabular}

Dengan demikian, komponen sasaran evaluasi proses dan hasil pembelajaran model EPS (Evaluasi Pembelajaran Sejarah), memiliki dua unsur pokok, yakni kualitas pembelajaran dan hasil pembelajaran. Aspek kualitas pembelajaran mencakup: kinerja guru sejarah, materi pembelajaran sejarah, metode pembelajaran, sarana pembelajaran, iklim kelas, sikap siswa, dan motivasi belajar sejarah. Sedangkan aspek hasil pembelajaran mencakup: kecakapan akademik, kesadaran sejarah, dan nasionalisme. Kualitas pembelajaran perlu dievaluasi secara kontinyu karena segingga mendukung keberhasilan pembelajaran. Semakin berkualitas proses pembelajaran, maka akan semakin tinggi tingkat efektivitas pembelajaran. Pembelajaran yang berkualitas didukung oleh kinerja guru yang baik dalam proses pembelajaran, materi pelajaran yang dikembangkan dengan baik, metode pembelajaran, sarana pembelajaran yang mendukung, iklim kelas yang kondusif, sikap siswa yang positif terhadap pelajaran sejarah, dan motivasi yang tinggi untuk berprestasi. Adapun unsur-unsur pokok tersebut dapat dibagankan dalam paradigma pada Gambar 2. di bawah ini.

Keberhasilan pelaksanaan pembelajaran sejarah di SMA harus dievaluasi secara komprehensif atau menyeluruh, yakni dengan mengevaluasi kualitas proses dan hasil belajar. Kualitas proses dalam penelitian ini menyangkut kualitas implementasi dalam kelas dan luar kelas, 
dan hasil belajar berupa capaian pelaksanaan pembelajaran. Hasil pembelajaran sangat dipengaruhi oleh kualitas proses pembelajaran. Evaluasi terhadap hasil pembelajaran sejarah tidak hanya mencakup kecakapan akademik saja, tetapi juga terhadap kesadaran sejarah dan nasionalisme.

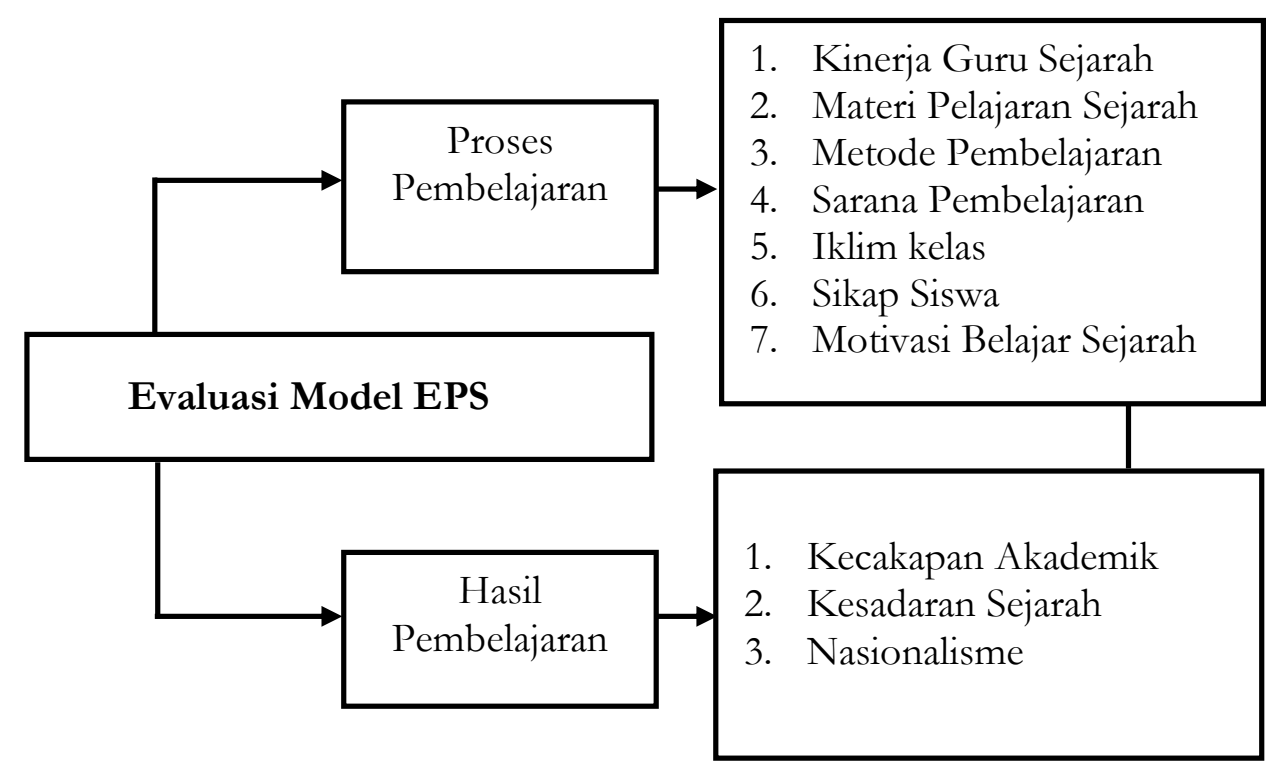

Gambar 2. Komponen-komponen Evaluasi Model EPS

Kegiatan pembelajaran merupakan interaksi antara guru dan siswa untuk mencapai tujuan tertentu. Kualitas pembelajaran tergantung pada kinerja guru sejarah dalam mengajar, materi pelajaran yang disajikan, metode pembelajaran, sarana pembelajaran, iklim kelas, sikap dan motivasi siswa dalam pembelajaran sejarah. Kegiatan guru dalam kegiatan belajar mengajar adalah manifestasi dari kinerja guru dalam mengajar, sedangkan kegiatan siswa di kelas merupakan manifestasi dari sikap dan motivasi belajar. Materi pelajaran yang representatif, metode pembelajaran yang dinamis, sarana pembelajaran yang mendukung, dan iklim kelas yang kondusif, akan berpengaruh pada sikap siswa, kinerja guru, dan motivasi 
belajar, serta hasil belajar. Kinerja guru yang baik akan berpengaruh pada: sikap siswa, motivasi, dan dengan dukungan sarana pembelajaran akan menimbulkan iklim kelas yang kondisif, dan berdampak pada hasil belajar siswa. Iklim kelas yang kondusif akan mempunyai pengaruh terhadap sikap dan motivasi belajar siswa serta hasil belajar siswa. Sikap positif siswa dalam proses belajar mengajar berpengaruh pada motivasi dan hasil belajar siswa, dan motivasi siswa akan berpengaruh pada hasil belajar siswa. Hasil belajar siswa mencakup kecakapan akademik kesadaran sejarah, dan nasionalisme.

Model evaluasi kualitas proses dan hasil pembelajaran sejarah, menekankan pada penilaian proses dan hasil belajar siswa dalam pembelajaran sejarah. Kemudian model ini diberi nama model evaluasi pembelajaran sejarah (EPS). Hasil pembelajaran sejarah mencakup kecakapan akademik, kesadaran sejarah, dan nasionalisme. Dengan demikian, model ini sangat praktis, karena dalam penilaian kualitas proses, penilaian juga mencakup input yang representasikan dalam proses. Model ini mengadopsi model CIPP (Contex, Input, Process, Product) dari Stufflebeam, dengan menekankan pada input, proses dan produk, yakni dengan mengevaluasi kualitas proses dan hasil pembelajaran sejarah. Di samping itu model EPS juga memodivikasi model EKO (Evaluasi Kualitas dan Output Pembelajaran) dari S. Eko Putro Widoyoko (2007). Pada model EKO, dirumuskan 5 komponen kualitas pembelajaran, sedangkan dalam model EPS dirumuskan 7 komponen kualitas pembelajaran sejarah. Out put dalam model EKO mencakup 3 komponen yaitu: kecakapan akademik, kecakapan personal, dan kecakapan sosial. Sedangkan dalam model EPS hasil pembelajaran mencakup 3 komponen yaitu: kecakapan akademik, kesadaran sejarah, dan nasionalisme.

\section{Simpulan}

Berdasarkan pada hasil penelitian dan pengembangan yang dilakukan, melalui proses pengumpulan dan analisis data, maka dapat dikemukakan simpulan penelitian sebagai berikut. Pertama, model evaluasi pembelajaran sejarah (EPS), memiliki dua komponen evaluasi yakni 
komponen kualitas pembelajaran dan hasil pembelajaran sejarah. Kualitas pembelajaran sejarah terdiri dari tujuh komponen, yakni: kinerja guru sejarah, materi pelajaran sejarah, metode pembelajaran, sarana pembelajaran sejarah, iklim kelas, sikap siswa, dan motivasi belajar sejarah. Sedangkan hasil pembelajaran sejarah terdiri dari tiga komponen yakni: kecakapan akademik, kesadaran sejarah, dan sikap nasionalisme.

Kedua, evaluasi model EPS hasil penelitian dan pengembangan ini memiliki kepekaan yang baik terhadap objek yang diteliti. Pada pelaksanaan uji coba pendahuluan, uji coba utama, dan uji coba operasional lapangan di lima Sekolah Menengah Atas (SMA) pada 618 subjek coba dapat mengungkap data yang diperlukan dengan baik. Klasifikasi sekolah yang diteliti melalui instrumen evaluasi menunjukkan kualitas sekolah yang bersangkutan. Hal itu dibuktikan juga dengan kriteria eksternal dengan menggunakan beberapa kriteria seperti (1) Kriteria Ketuntasan Minimal (KKM) yang menunjukkan klasifikasi sekolah, (2) tingkat perhatian sekolah terhadap pembelajaran sejarah, (3) tingkat pencapaian prestasi di bidang sejarah seperti perolehan medali lomba-lomba bernuansa kesejarahan, (4) akreditasi sekolah, dan (5) tingkat pencapaian nilai UAS. Ketiga, tingkat koherensi instrumen EPS ketika digunakan untuk menilai kualitas dan hasil pembelajaran sejarah sesuai dengan rancangan. Instrumen yang digunakan untuk menggali data di lapangan dapat memberikan informasi yang baik, saling mendukung dan melengkapi antara data yang sifatnya kuantitatif dengan statistik deskriptif, didukung oleh data kualitatif yang dianalisis dengan model analisis interaktif.

Keempat, model EPS memiliki beberapa karakteristik yang membedakan dengan evaluasi model lain, yakni: (a) model digunakan untuk mengevaluasi pelaksanaan pembelajaran sejarah di Sekolah Menengah Atas; (b) tidak tergantung pada pendekatan pembelajaran tertentu yang dilaksanakan oleh guru; (c) komprehensif (mengevaluasi kualitas pelaksanaan sekaligus hasil pembelajaran sejarah); (d) dapat digunakan sebagai evaluasi diagnostik (diagnostic evaluation); (e) bersifat terbuka untuk dikembangkan lebih lanjut. Kelima, kelebihan model EPS dalam proses implementasi di sekolah yaitu: (a) komprehensif, (b) sederhana, (c) pleksibel, (d) efektif, dan (e) oriented. Dengan demikian, sebagai masukkan 
bagi kepala sekolah dan guru sejarah bahwa program pembelajaran sejarah sebaiknya dievaluasi secara berkesinambungan sehingga tujuan pembelajaran sejarah secara substansial dapat tercapai. Perangkat model EPS dalam hal ini, baik untuk digunakan sebagai alat evaluasi dalam pelaksanaan program pembelajaran sejarah.

\section{Dafatar Pustaka}

A. Syafii Maarif. 2006. "Harmonisasi antara nasionalisme dalam kehidupan bernegara dan beragama”, dalam kearifan sang profesor. Yogyakarta: Universitas Negeri Yogyakarta Press.

A. Daliman. 2006. "Harmonisasi antara nasionalisme dalam kehidupan bernegara dan beragama”, dalam kearifan sang profesor. Yogyakarta: Universitas Negeri Yogyakarta Press.

Amstrong Michael and Helen Murlis. 2003. Reward management: a hand book of remuneration strategy and practice. Jakarta: Gramedia.

Borg, W.R. \& Gall, M.D. 1983. Educational research: an introduction. NewYork \& London: Longman.

Brannen, Julia. 1993. Mixing method: qualitative and quantitative research. Aldershot, Brookfield USA, Hong Kong, Singapore, Sydney: Albebury.

Carolin Rekar Munro. 2005. "Best practices" in teaching and learning: challenging current paradigms and redefining their role in education. The College Quarterly. 8 (3), 1 - 7.

Depdiknas.2006. Peraturan mendiknas nomor 22 tahun 2006. Jakarta: Departemen Pendidikan Nasional.

Djemari Mardapi.2005. "Pengembangan sistem penilaian berbasis kompetensi”. Dalam bimpunan evaluasi Indonesia (HEPI). Yogyakarta: Program Pascasarjana Universitas Negeri Yogyakarta. 
Jurnal Penelitian dan Evaluasi Pendidikan

Djemari Mardapi. 2011. Pengembangan penilaian instrumen dan kisi-kisinya. Yogyakarta: PPS Universitas Negeri Yogyakarta.

Djoko Suryo.2005. "Paradigma sejarah di Indonesia dan kurikulum sejarah", dalam makalah seminar nasional dan temu alumni program studi pendidikan sejarah Program Pascasarjana Universitas Sebelas Maret Surakarta. Surakarta: PPS UNS.

Fernandes, H.J.X. 1984. Evaluation of educational programs. Jakarta: National Educational Planning Evaluation and Curriculum Development.

Gay, L.R. 1981. Educational research: competencies for analysis \& application. Ohio: Charles E. Merril Publishing Co.

Ian Phillips. 2008. Teaching history: Developing as a reclective secondary teacher. London: Sage.

Pujiati Suyata. 2011. Validitas logis dan validitas empiris instrument penilaian dengan teknik tes. Yogyakarta: Universitas Negeri Yogyakarta.

Rochiati Wiriaatmaja. 2004. "Multicultural perspective in teachhing history to the Chinese Indonesian Studies", dalam historia: jurnal pendidikan sejarah, no.9 vol.v. Bandung: Jurusan Pendidikan Sejarah UPI.

Sam Wineburg. 2006. Historical thingking and other unnatural acts charting the future of teaching the fast. Jakarta: Yayasan Obor Indonesia.

Sartono Kartodirdjo. 1999. Multidimensi pembangunan bangsa etos nasionalisme negara kesatuan. Yogyakarta: Kanisius.

S. Eko Putro Widoyoko. 2007. Pengembangan model evaluasi pembelajaran IPS di SMP. Yogyakarta: Disertasi Program Pasca Sarjana Program Studi Penelitian dan Evaluasi Pendidikan Universitas Negeri Yogyakarta.

Suharsimi Arikunto. 2001. Dasar-dasar evaluasi pendidikan. Jakarta: Penerbit Bumi Aksara.

Suharsimi Arikunto. \& Cepi Safruddin AJ. 2004. Evaluasi program pendidikan, panduan teoritis praktis bagi praktisi pendidikan. Jakarta: Bumi Aksara.

456 - Jurnal Penelitian dan Evaluasi Pendidikan Tahun 16, Nomor 2, 2012 